\title{
レポート REPORT
}

\section{道路整備における保全対策技術〜海浜植生の復元技術事例}

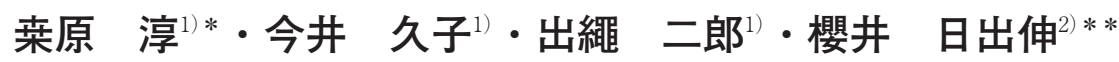

1）株式会社 環境アセスメントセンター テ420-0047 静岡県静岡医葵区清閉町 13-12

2）国土交通省中部地方整備局四日市港湾事務所Ｆ５10-0064 三重県四日市市新正三丁目 7 番27号

\section{Atsushi KUWABARA ${ }^{1)}$, Hisako IMAI ${ }^{1)}$, Jirou DENAWA ${ }^{1)}$, Hidenobu SAKURAI ${ }^{2}$ : Technology for conservation measures in road construction: Examples of restoration technology for beach vegetation. Ecol. Civil Eng.}

1) Co., Ltd. Environmental Assessment Center, 13-12 Seikancho, Aoi-ku, Shizuoka, Shizuoka 420-0047, Japan

2) Yokkaichi Port Office, Chubu Regional Development Bureau, Ministry of Land, Infrastructure, Transport and Tourism, 3-7-27 Shinsho, Yokkaichi City, Mie 5100064, Japan

\section{はじめに}

三重県の海岸線は $1,110 \mathrm{~km}$ で, 全国で 7 番目とされ る。このうち, $600 \mathrm{~km}$ 程度が自然海岸, その $100 \mathrm{~km}$ 程 度が砂浜海岸である。また，三重県の伊勢湾海区には， 800 ha 程度の干潟が現存している. 開発などによってこ れらの干潟や砂浜が消滅しつつある三重県の北勢地域 (伊勢湾北部) では, 高松海岸は半自然海岸（海岸（汀 線）の一部に人工構築物があるが, 潮間带においては自 然の状態を保持している海岸)（環境省 1980 ; 三重県 2015）として残る貴重な海岸である。このため, 三重県 や周辺自治体では, 高松海岸を環境や景観の保全を推進 する場所として位置づけている。 また, 砂浜や干潟を代 表する植物だけでなく, 自然度の高い河口や河岸の砂地 で見られるナギサッルギアブ (Acrosathe stylata) の生息 地, 三重県の鳥として親しまれているシロチドリ（Char adrius alexandrinus）の周年生息地，ズグロカモメやシ ギ・チドリ類の越冬地や渡り鳥の中継点となっている (三重県 2015)。このため, 三重レッドデータブック
2015（三重県 2015）では，高松海岸は様々な生物の重 要な生息場所として,「ホットスポットみえ（希少野生 動植物主要生息生育地)」に位置づけられている.

四日市港臨港道路（霞 4 号幹線）は, 四日市港霞ヶ浦 南ふ頭から町道川越中央線（臨海橋）を結ぶ約 $4.1 \mathrm{~km}$ の臨港道路で，2018 年 4 月 1 日開通した。この道路は, 1）生活・産業を支える四日市港の発展として, 増大す る港湾関連交通を円滑に高速交通網に連絡することによ り, 定時性・即時性が確保され, 港湾貨物の輸送コス卜 削減や，港湾サービス水準の向上を図ること，2）周辺 道路への負荷の軽減として，増大寸ることが予測される 港湾関連交通を, 周辺道路（国道 23 号）へ環境負荷を かけることなく背後地へと結ぶこと，3）霞大橋一本の みで結ばれた出島方式の霞ヶ浦ふ頭に対し，災害時など の緊急物資輸送や霞ヶ浦ふ頭内で働く労働者などの安 心・安全確保といった, 災害時のリダンダンシー（代替 機能）の確保に期待された道路である（臨港道路霞 4 号 幹線調査検討委員会 2003a；林・葉原 2017).

この「霞 4 号幹線」は高松海岸の一部を通過するため,

\section{1 年 2 月 25 日受付, 2021 年 6 月 16 日受理}

\section{早期公開 (J-STAGE)}

J-STAGE Advance published doi: https://doi.org/10.3825/ece.21-00003

*e-mail: kuwabara@eac-net.co.jp

**現所属：国土交通省 中部地方整備局 清水港湾事務所 御前崎港事務所 †437-1623 静岡県御前崎市港 6170

** Present Address : Shimizu Port Office, Omaezaki Port Office, Chubu Regional Development Bureau, Ministry of Land, Infrastructure, Transport and Tourism, 6170, Minato, Omaezaki City, Shizuoka 437-1623, Japan 
その整備にあたっては，「海岸や干潟の多様な機能の保 全を目指す」ことが，臨港道路霞 4 号幹線調查検討委員 会（主管：四日市港管理組合）による「提言と付帯意見 及び道路ガイドプラン」（H15 年 3 月）（臨港道路霞 4 号 幹線調查検討委員会 http://www.yokkaichi-port.or.jp/ka sumi_r4/index.html，2021 年 2 月 23 日確認）に抢いて示 されている。この提言に基づいて，高松海岸や干潟の多 様な機能の保全を目指し, 重要な動植物の移植や遮光板 の設置など，各種の環境保全対策が実施されてきた。 「臨港道路霞 4 号幹線調査検討委員会」閉会後, これら の環境保全対策の結果に基づいて，先述した付帯意見と の整合を図りながら霞 4 号幹線事業の実施に反映できる よう，助言・指導をする「臨港道路霞 4 号幹線事業実施 に伴う懇談会」（主管：国土交通省中部地方整備局四日 市港湾事務所）が設置されている（2017 年 12 月で閉会）.

本報告の海浜植生の復元を検討するにあたっても，懇 談会において有識者や関係機関などから助言・指導をい ただきながら，検討を進めてきた。海岸部に成立する植 生を対象に復元技術には，これまでの現場実績の蓄積に よって，その手法が確立されている海岸林の造林技術 (森林総合研究所 2015 ほか) や, 人工的に海浜部を創 出した事例（岡 2010）, 個々の海浜性植物を対象とした 植生の復元試験を実施した事例（例えば，宮本・西川
1999 ；清水 2016 ; 野口 2009）がある。しかし，本報告 のような，道路整備に伴い撤去した範囲（約 $1 \mathrm{ha} ） を$ 備し，残存する海浜植生との連続性などを考慮した配植 を検討したうえで，現地調達した海浜性植物を用いて海 浜植生を復元する，という一連の工程を報告した事例は 全国的にも少ない，本報告では，この海浜植生の復元技 術事例の詳細について紹介する。

\section{調查地の状況}

海浜植生の復元は，三重県川越町の朝明川河口右岸側 に形成された高松海岸のうち，四日市港臨港道路（霞 4 号幹線）の整備の際に撤去した約 1 ha の整備撤去範囲 を対象に実施した（Fig. 1）.

高松海岸には，ハマヒルガオ（Calystegia soldanella） やコウボウシバ (Carex pumila)，コウボウムギ（Carex kobomugi）などの砂浜や干潟を代表する海浜性植物の優 占する, 東西 $400 \mathrm{~m}$ 程度, 奥行き $100 \mathrm{~m}$ 程度の海浜植生 が成立している。主な海浜植生には，ハマヒルガオ群落， コウボウシバ群落，コウボウムギ群落，ケカモノハシ群 落，ハマゴウ群落がある。このほか，草本植生ではナガ ミノオニシバ群落，ススキ群落，チガヤ群落，木本植生 ではハリエンジュ群落やセンダン群落が成立している。

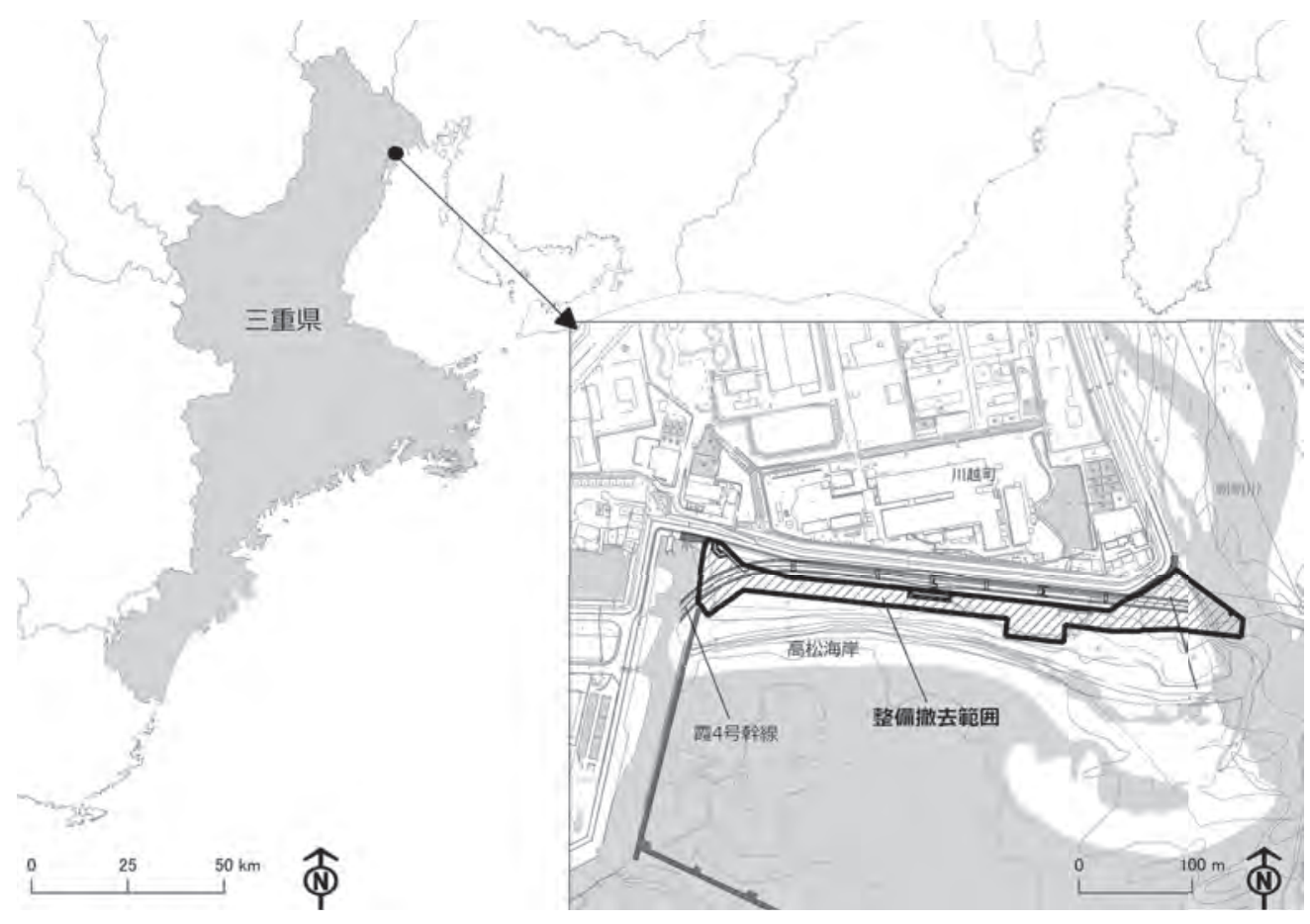

Fig. 1. Location of Takamatsu coast where restoration construction of beach vegetation was carried out. 海浜植生を復元した高松海岸の位置. 


\section{方 法}

復元工事は, 2016 年の概略検討からはじまり，2017 年の詳細検討を経て 2018 年 8 月に開始した（Fig. 2). 復元工事の期間は約 3 ヶ月間で, 2019 年 1 月に完了した.

\section{概略検討}

概略検討においては，海浜植生を構成する海浜性植物 群落の成立条件を把握し, その結果から復元目標の設定 や復元植生の配植の考元方（基本的な方針）を検討した.

\section{海浜植生の成立条件}

2016 年 8 月, 整備撤去範囲に海浜植生を復元する際 の基本条件となる海浜植物の生育位置と高松海岸の地盤 高との関係を把握するため, ライントランセクト調査を 実施した。この調査では, 地形横断測量（間接水準）に よる地形形状の計測とライン上の海浜性植物や主な内陸 性植物の出現位置を記録し, 種ごとの生育地盤高の特徵
を把握している。

計 4 測線を対象としたライントランセクト調査の結果, 海浜性植物は地盤高の低い場所（汀線側）から高い場所 （海岸堤防側）に向かって，アキノミチヤナギ（Polygonum polyneuron) $\rightarrow$ コウボウシバ $\rightarrow$ ハマヒルガオ $\rightarrow$ コウ ボウムギーケカモノハシ (Ischaemum anthephoroides) ーハマゴウ（Vitex rotundifolia）の順で出現していた. これらの植物の優占する海浜性植物群落の分布様式は, いわゆる「成带構造（ゾーネーション）」と呼ばれるも のであり，高松海岸においても，この「成帯構造」を観 察することができた（Fig. 3)。ただし，汀線側から海岸 堤防側に向かう場合は, 水域 $\rightarrow$ 自然裸地 $\rightarrow$ ハマルガオ

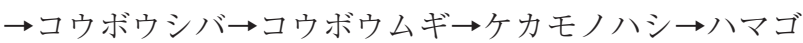
ウとなるのに対し，海岸の東西にある河川やワンドから





\begin{tabular}{|c|c|c|c|c|c|c|}
\hline 2016 年 & 2017 年 & \multicolumn{4}{|c|}{2018 年 } & 2019 年 \\
\hline & & 8月 & 9月 & 10 月 & 10 月 24 日 & 1月 29 日 \\
\hline $\begin{array}{l}\text { 概略 } \\
\text { 検討 }\end{array}$ & $\begin{array}{l}\text { 詳細 } \\
\text { 検討 }\end{array}$ & $\begin{array}{l}\text { 复元範囲 } \\
\text { 刀確認 }\end{array}$ & $\begin{array}{l}\text { 伐採 } \\
\text { 除根 }\end{array}$ & $\begin{array}{l}\text { 整地 } \\
\text { 志配調整 }\end{array}$ & $\begin{array}{l}\text { 移植 } \\
\text { 開始 }\end{array}$ & $\begin{array}{l}\text { 移植 } \\
\text { 完了 }\end{array}$ \\
\hline
\end{tabular}

Fig. 2. Beach vegetation restoration construction process 海浜植生の復元工事の工程.

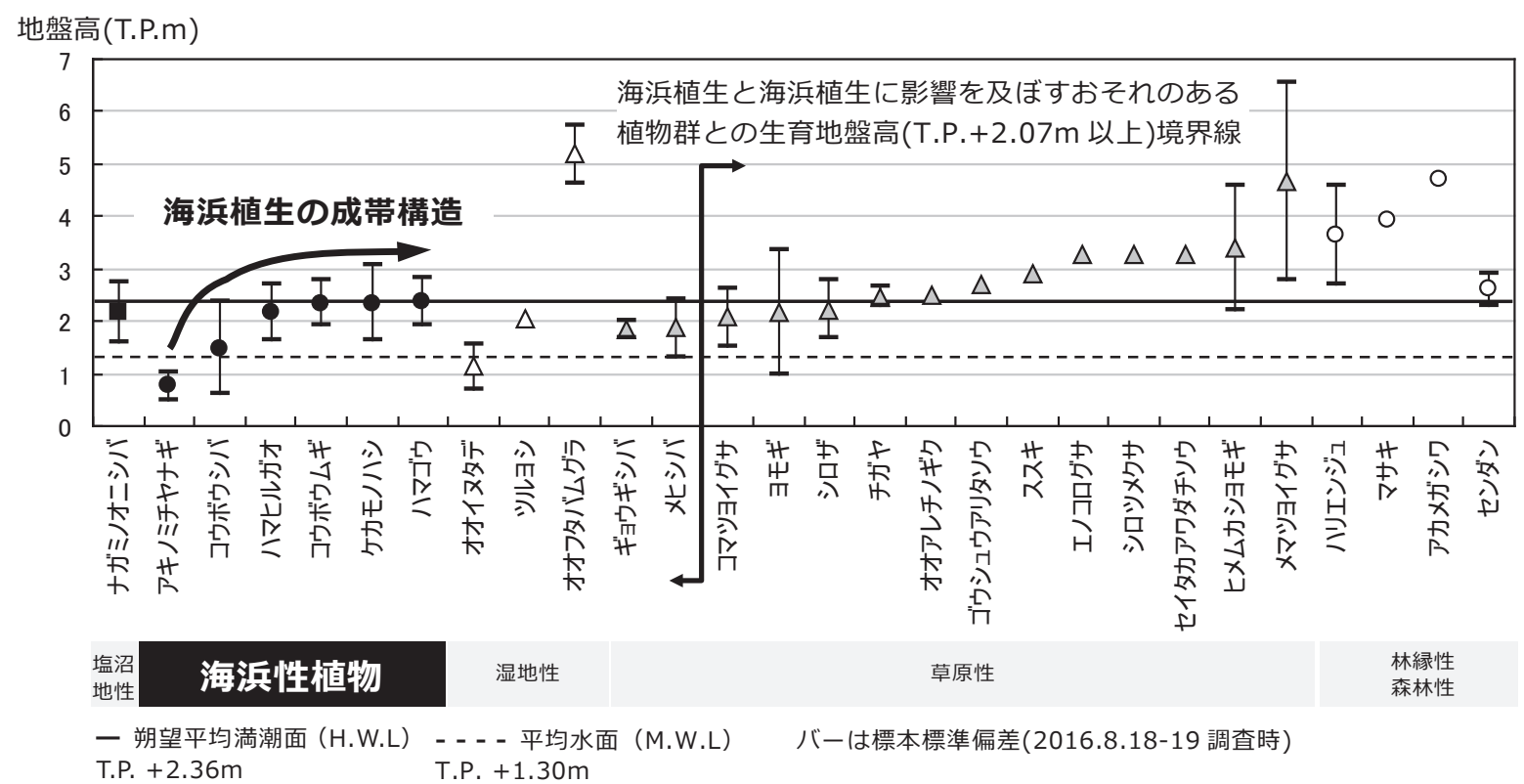

Fig. 3. Relationship between plants and ground height(T.P.m). 植物と地盤高（T.P.m）の関係. 
ハマヒルガオが欠落する。この違いは, 比高が低く, 土 壤含水率の高い立地を好む（宮脇-奥田編 1990 ; 早 坂 ·藤原 2006 ; 岡ほか 2007 ; 楠瀬 ·石川 2014）が, 波による攪乱への耐性が弱い（楠瀬・石川 2014）とい う、コウボウシバの特性を反映したものである。高松海 岸において, 成带構造を踏まえた海浜植生の復元を検討 する際には，このような種ごとの分布様式の違いを考慮 しなければならない.

一方, 内陸性植物は安定帯に出現する海浜性植物（ケ カモノハシやハマゴウ）と同じかそれ以上の地盤高で出 現していた (Fig. 3)。この結果から, 内陸性植物が海浜 性植物と同所的に生育可能な陸側の地盤高の高い場所 （海岸堤防側）に执いて, 復元工事の際に内陸性植物が 移植苗と混生して非意図的に植え付けられた場合, 復元 目標とする群落の成立に影響を及ぼす危険性のあること がわかった。この点は, 復元工事の際の留意点として整 理している.

\section{海浜植生の復元目標の方針}

ライントランセクト調查の結果をもとに, 整備撤去範 囲に復元する海浜植生の目標を, コウボウシバ群落, コ ウボウムギ群落, ケカモノハシ群落, ハマゴウ群落の 4 つの群落に設定した。高松海岸では，これらの群落は 1 種の海浜性植物が優占する場合と, 複数の種が混生して 成立している場合があった。このため, 海浜植生を復元 する際には，1種が優占種となる「純群落」と，優占種 とそれ以外の構成種（=準優占種）が混生する「複合群 落」を復元群落の目標とする方針とした.

なお，高松海岸の主な海浜植生の一つであるハマヒル ガオ群落は復元目標に設定しなかった．汀線側から海岸 堤防側に向かう場合の成带構造を考慮した場合, 汀線か ら離れた海岸堤防側に位置する整備撤去範囲の復元目標 として, 最も汀線側に分布するハマヒルガオ群落を設定 することは適切ではないと判断したためである.

\section{海浜植生の配植の方針}

整備撤去範囲に復元する海浜植生は, 個々の海浜性植 物群落の分布特性や高松海岸の景観的な観点からも, 整 備撤去範囲外に残る海浜植生との連続性を考慮しなけれ ばならない。このため, 高松海岸で観察された成带構造 を踏まえ, 整備撤去範囲で, 汀線側の地盤高のやや低い 放水路側㧍よび朝明川沿いの立地には, 冠水状態に耐性 のあるコウボウシバ群落, その背後（陸側）にはコウボ ウムギ群落, さらに陸側にケカモノハシ群落, 汀線から 最も離れた地盤高の高い海岸堤防側には, 安定帯に成立 するハマゴウ群落を配植するという基本的な配植方針を
定めた.

\section{詳細検討}

2016 年に検討した概略検討を踏まえ, 翌 2017 年に海 浜植生の復元に必要な詳細な条件を検討した。

\section{整備撤去範囲の区域区分の決定}

概略検討段階までの海浜植生の復元の検討は, 整備撤 去範囲を対象にしたものである. しかし, 詳細検討の段 階で, 海浜植生の復元範囲を整備撤去範囲の海側に隣接 するハリエンジュ（Robinia pseudoacacia）やセンダン (Melia azedarach var. subtripinnata) などの優占する低木 林も含めた（Fig. 4).これは, ハリエンジュなどの低木 林を整地することで, その背後地（陸側）に位置する整 備撤去範囲が砂の移動, 飛塩, 風などの影響（攪乱）を より受けやすくなる環境, つまり海浜性植物の生育に適 した環境に整備することを目的としたためである。同時 に, ハリエンジュやセンダンの分布拡大とそれに伴う森 林化が進む高松海岸において, 海浜性植物を主要構成種 とする自然草原が維持されるよう, 海浜植生の “質”の 低下を抑制するための措置でもあった。

海浜植生の復元は整備撤去範囲と一部範囲外を含む範 囲となり，その面積は計 $9,805 \mathrm{~m}^{2}$ となった（Fig. 5). さらに, 整備撤去範囲の地盤高, 整備撤去範囲外の海浜 植生の分布, ハリエンジュなどの低木林の除去後の状況 を考慮し，計 11 の復元区域に区分した（Fig. 5)。なお， 整備撤去範囲のうち, 朝明川沿い $\left(2,246 \mathrm{~m}^{2}\right)$ の立地は 河川区域内に位置しているため, 自然裸地（干潟）と位 置づけ, 海浜植生の復元範囲には含めなかった.

\section{復元する海浜性植物群落と優占種の構成パターンの決定}

復元する海浜植生は, 概略検討での海浜植生の復元目 標（考え方）を踏まえ，コウボウシバ群落，コウボウム ギ群落, ケカモノハシ群落, ハマゴウ群落の 4 つの海浜 性植物群落とし, 各群落の構成から 6 つの構成パターン を設定した（Table 1)。この構成パターンは，優占種 1 種を移植するパターン（以下, 純群落) と, 優占種とは 別の海浜性植物 1 種以上を移植するパターン（以下, 複 合群落) である。このように同じ構成種であっても, 優 占種の異なるパターンを設定することは, 高松海岸にお ける海浜植生の多様性を維持する上で重要なことである.

\section{配植の決定}

海浜植生の復元範囲 $\left(9,805 \mathrm{~m}^{2}\right)$ で区分した 11 区域に, 前項で決定した海浜性植物群落の6つの構成パターンを 配植した（Table 2, Fig. 6)。この配植では, はじめに 純群落の配置を, 復元区域の地盤高と地形形状を参考に 決定した（Fig. 6, (1)コウボウシバ群落, (5)ハマゴウ群 


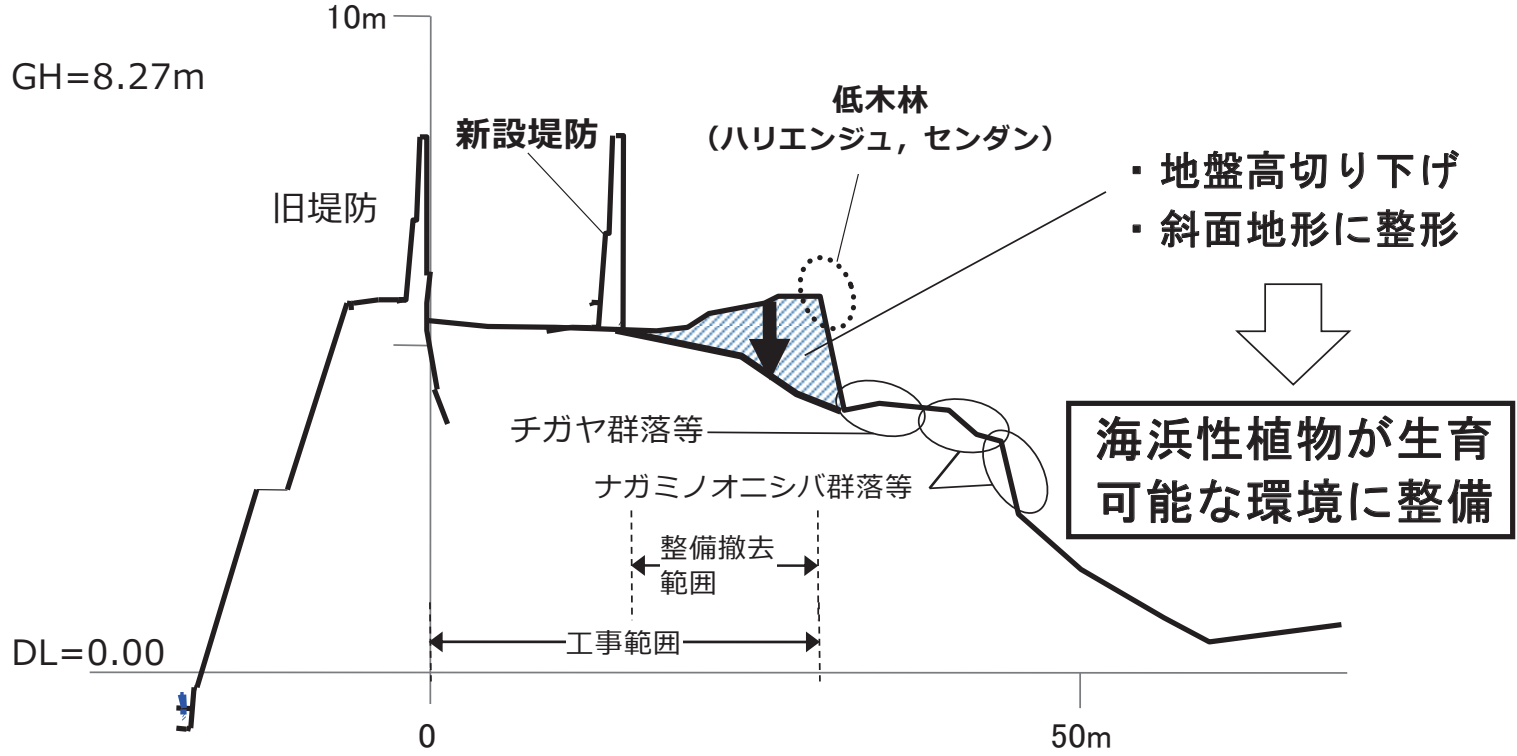

Fig. 4. Image of devaluation of ground height at the place where shrub forest (Robinia pseudoacacia, Melia azedarach var. subtripinnata, etc.) was established 低木林（ハリエンジュ，センダン等）成立箇所の地盤高切り下げのイメージ.

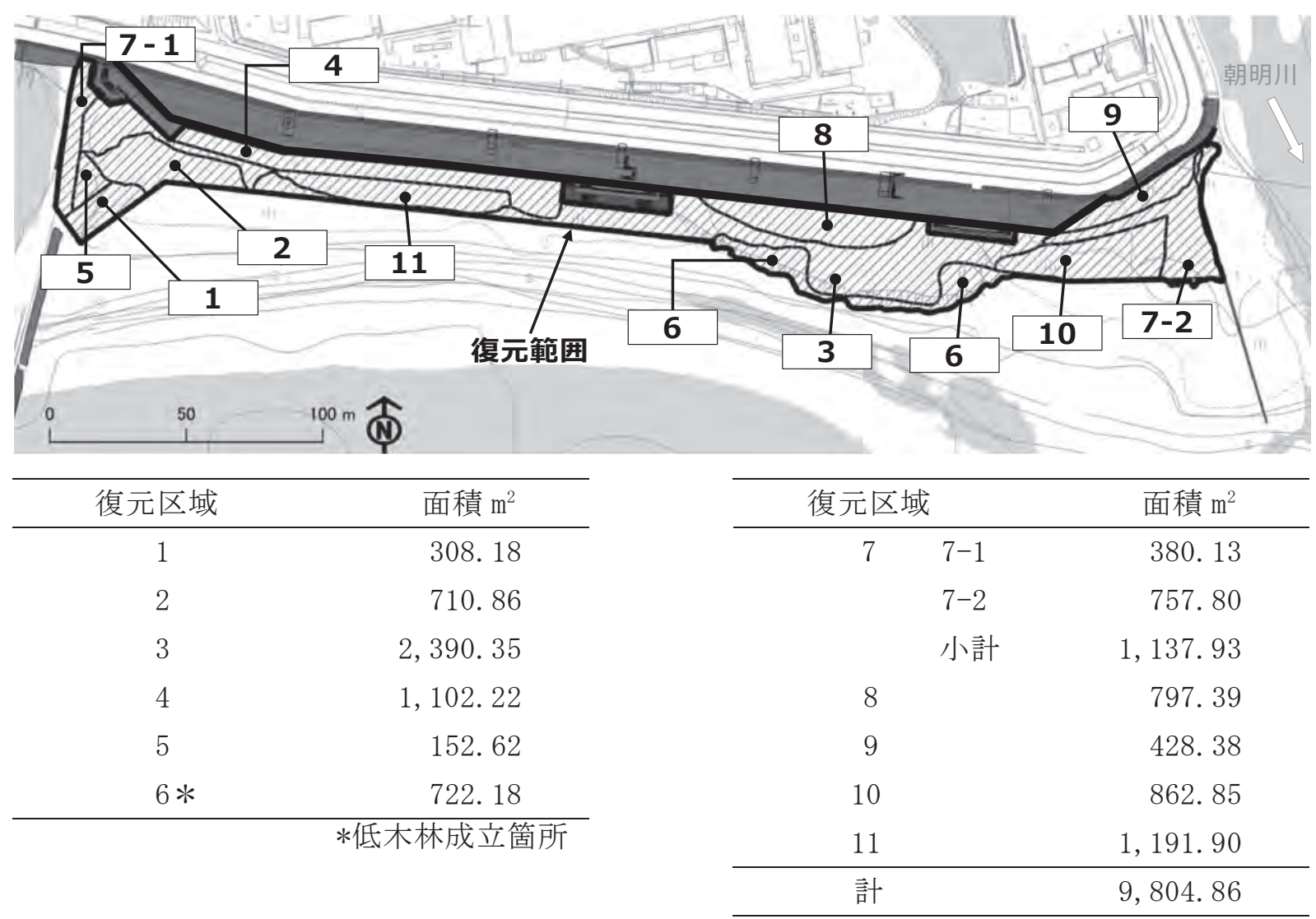

Fig. 5. Restoration range of beach vegetation, area division (1-11) and area. 海浜植生の復元範囲, 区域区分 $(1 \sim 11)$ と面積. 
Table 1. Vegetation restoration target Community composition of beach plants. 植生復元の目標群落と海浜性植物の構成.

\begin{tabular}{|c|c|c|c|}
\hline & 目標群落 & 優占種 & 構成種 \\
\hline 1 & コウボウシバ群落 & コウボウシバ & なし \\
\hline 2 & コウボウシバ群落 & コウボウシバ & ケカモノハシ \\
\hline 3 & コウボウムギ群落 & コウボウムギ & ハマゴウもしくはケカモノハシ \\
\hline 4 & ケカモノハシ群落 & ケカモノハシ & コウボウムギもしくはコウボウシバ \\
\hline 5 & ハマゴウ群落 & ハマゴウ & なし \\
\hline 6 & ハマゴウ群落 & ハマゴウ & コウボウシバ \\
\hline
\end{tabular}

落)，次に，復元範囲外に残る海浜植生と純群落の位置 関係から，複合群落の配置を決定した（Fig. 6，(2)コウ ボウシバ群落，(3)コウボウムギ群落，(4)ケカモノハシ群 落，(6)ハゴウ群落)。これは，群落の構成種である海 浜性植物が地盤高（地形形状）の変化に合わせ，連続的 に変化していく状態を考慮したものである.

\section{復元に使用する海浜性植物の調達}

4 つの海浜性植物群落（コウボウシバ群落, コウボウ ムギ群落, ケカモノハシ群落，ハマゴウ群落）を復元す るためには，これらの優占種あるいは構成種となる 4 種 の海浜性植物（ハマゴウ, ケカモノハシ, コウボウムギ, コウボウシバ）を導入（移植）しなければならない.

先述したように, 高松海岸やその前面の干潟は三重県 のレッドデータブック 2015 に扔いて「希少野生動植物 主要生息生育地（ホットスポットみえ）」として位置つ けられている。また，三重県内では，この海岸のみで記 録のある昆虫類も生息している。海浜植生の復元に使用 する植物を調達する際には, このような高松海岸の環境 特性や地域固有性に十分配慮しなければならない。そこ で，復元に使用する 4 種の海浜性植物の移植苗は，流通 苗の購入や他海岸からの持ち込みなどは行わず，全て当 該海岸から調達（採取）することとした，移植苗を採取 する調達先は整備撤去範囲外に残るハマゴウ群落, ケカ モノハシ群落, コウボウムギ群落, コウボウシバ群落の 4 群落が対象となる。しかし, これらの調達（採取）は 海浜性植物群落に対する攪乱であり，その圧が大きくな った場合，これらの群落の衰退を招く㧍それがある。こ のため, 調達（採取）による影響を最小限に抑えるため, 面的に剥ぎ取るようなことはせず，主に群落の辺縁部を 調達 (採取) 対象とした。また, 調達 (採取) する際に は, 掘り取る移植苗同士の間隔をあけ，間引いて採取す る方法を採用した。

\section{移植密度・数量の決定}

各海浜性植物の移植密度は, 整備撤去範囲内の海浜植
生を復元する際の一助となる数量で設定する必要がある. その一方で, 整備撤去範囲外に残る海浜植生に影響を与 えない程度の数量に設定しなければならない。このため, 移植密度 (調達数量) は, 掘り取り数量と現地調達の可 能な数量とのバランスを考虑し, 植生復元に必要な最小 数量となるように検討した。

4 種類の海浜性植物うち, 八マゴウとケカモノハシは, 移植密度に関する既往研究を見つけることができなかっ た。このため, 現地の生育状況などを参考に, 移植密 度・数量を設定することとした。一方，コウボウムギは 既往研究による移植事例があり, その研究成果を活用す ることで, 本種の移植後の活着確度をより高めることが 可能であると判断した．また，コウボウムギと同様の繁 殖特性を有するコウボウシバも同様である.

ハマゴウは 2013 年の試験移植個体のモニタリングに 招いて調查対象とした最低密度「2 個体 $/ \mathrm{m}^{2} 」 を$ 移植密 度として採用した，ハマゴウは匍匐茎が裸地に向かって 伸長するという繁殖特性がある，本種の移植密度の設定 は，この点を考慮し，活着後の匍匐茎の伸長方向を確保 し，伸長成長がより促されることを期待したものである.

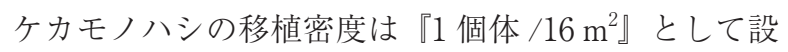
定した。本種が高松海岸で群落を形成している場所では, 各個体の分布間隔は $3 \mathrm{~m}$ 未満が中心で, $4 \mathrm{~m}$ を超えて分 布している個体数は少なかった。このため, 個々のケカ モノハシが「群落」を形成していると認識できる分布間 隔は $4 \mathrm{~m}$ 程度（ $4 \mathrm{~m} \times 4 \mathrm{~m}$ の範囲に 1 個体）が限界值と なる。ケカモノハシは種子繁殖によって分布を拡大する が, 高密度に移植した場合, 種子による新規参入個体の 定着が難しくなる可能性がある。本種の移植密度の設定 は，飛散した種子が裸地に定着し，成長することを期待 したものである。

コウボウムギは移植間隔を密 $\left(1 \mathrm{~m}\right.$ 間隔 $=1$ 個体 $\left./ \mathrm{m}^{2}\right)$ に設定した場合，平面的な被覆率が高まることが知られ ている（移植後 4 年目に $1 \mathrm{~m}^{2}$ の $60 \%$ 程度を被覆）（鈴 
Table 2. Restoration target of beach vegetation and procurement quantity of beach plants required for restoration.

海浜植生の復元目標ごとに必要な海浜性植物の調達数量.

\begin{tabular}{|c|c|c|c|c|c|c|}
\hline \multirow{2}{*}{ 区域 } & \multicolumn{3}{|c|}{ 復元目標 } & \multirow{2}{*}{ 植栽植物 } & \multicolumn{2}{|c|}{ 調達数量 } \\
\hline & \multicolumn{2}{|c|}{ 群落等※( )内は随伴種 } & 面積 $\mathrm{m}^{2}$ & & 株数 & 計 \\
\hline 1 & \multicolumn{2}{|c|}{ コウボウシバ群落 } & 308.18 & コウボウシバ & 617 & 617 \\
\hline \multirow{2}{*}{2} & \multirow{2}{*}{\multicolumn{2}{|c|}{$\begin{array}{l}\text { コウボウシバ群落 } \\
\text { (ケカモノハシ) }\end{array}$}} & \multirow{2}{*}{710.86} & コウボウシバ & 1,422 & \multirow{2}{*}{1,467} \\
\hline & & & & ケカモノハシ & 45 & \\
\hline \multirow{3}{*}{3} & \multirow{3}{*}{\multicolumn{2}{|c|}{$\begin{array}{l} \\
\text { コウボウムギ群落 } \\
\text { (ハマゴウ, ケカモノハ })\end{array}$}} & \multirow{3}{*}{$2,390.35$} & コウボウムギ & 1,214 & \multirow{3}{*}{2,063} \\
\hline & & & & ハマゴウ & 697 & \\
\hline & & & & ケカモノハシ & 152 & \\
\hline 4 & \multicolumn{2}{|c|}{ ハマゴウ群落 } & $1,102.22$ & ハマゴウ & 2,226 & 2,226 \\
\hline 5 & \multicolumn{2}{|c|}{ コウボウシバ群落 } & 152.62 & コウボウシバ & 306 & 306 \\
\hline \multirow{2}{*}{6} & \multirow{2}{*}{\multicolumn{2}{|c|}{$\begin{array}{l}\text { コウボウシバ群落 } \\
\text { (ケカモノハシ) }\end{array}$}} & \multirow{2}{*}{722.18} & コウボウシバ & 1,445 & \multirow{2}{*}{1,491} \\
\hline & & & & ケカモノハシ & 46 & \\
\hline $7-1$ & \multirow{2}{*}{\multicolumn{2}{|c|}{ コウボウシバ群落 }} & 380.13 & コウボウシバ & 381 & \multirow{2}{*}{1,139} \\
\hline $7-2$ & & & 757.8 & コウボウシバ & 758 & \\
\hline 8 & ハマゴウ & & 797.39 & ハマゴウ & 3,988 & 3,988 \\
\hline \multirow{2}{*}{9} & \multirow{2}{*}{\multicolumn{2}{|c|}{$\begin{array}{l}\text { ハマゴウ群落 } \\
\text { (コウボウシバ) }\end{array}$}} & \multirow{2}{*}{428.38} & ハマゴウ & 857 & \multirow{2}{*}{1,286} \\
\hline & & & & コウボウシバ & 429 & \\
\hline \multirow{2}{*}{10} & \multirow{2}{*}{\multicolumn{2}{|c|}{$\begin{array}{l}\text { ハマゴウ群落 } \\
\text { (コウボウシバ) }\end{array}$}} & \multirow{2}{*}{862.85} & ハマゴウ & 1,726 & \multirow{2}{*}{2,589} \\
\hline & & & & コウボウシバ & 863 & \\
\hline \multirow{3}{*}{11} & & & & ケカモノハシ & 75 & \\
\hline & $\begin{array}{l}\text { ケカモ) } \\
\text { (コウボ }\end{array}$ & $\begin{array}{l}\text { シ群洛 } \\
\text { ギ,コウボウシバ) }\end{array}$ & $1,191.90$ & コウボウムギ & 606 & 1,268 \\
\hline & & & & コウボウシバ & 587 & \\
\hline & 総計 & & $9,804.85$ & & & 18,440 \\
\hline & 元植物 & 数量(株) & & & & \\
\hline コウ & ボウムギ & 2,338 & & & & \\
\hline コウ & ボウシバ & 6,290 & & & & \\
\hline ケカ & Eノハシ & 318 & & & & \\
\hline ハマ & エ゙ウ & 9,494 & & & & \\
\hline & 計 & 18,440 & & & & \\
\hline
\end{tabular}

木 1974；田中ほか 2002)。コウボウムギを移植した場 合, 1 年以内に約 6 割が枯死する観察事例がある（遠州 灘海岸での事例, 108 株 $\rightarrow$ 約 40 株）（野口 2010）。これ らの分布拡大扔よび移植後の生残率に関する研究報告事 例を踏まえ, 高松海岸の海浜植生復元範囲にコウボウム ギを移植する場合の移植密度を，「移植後 4 年目に少な くとも 1 個体が生残し (生残率約 40\%)，それが被覆率 60\%程度となるように成長する」条件で設定する必要が
ある。また、コウボウムギならびにコウボウムギと類似 した生態的特性を持つコウボウシバの移植密度も「3 個 体 $/ \mathrm{m}^{2} 」$ として設定した。

このように，ハマゴウ，ケカモノハシ，コウボウムギ, コウボウシバの移植密度を植生復元に必要な最低数量と した場合，移植に必要な数量は計 18,440 株となった (Table 2). 


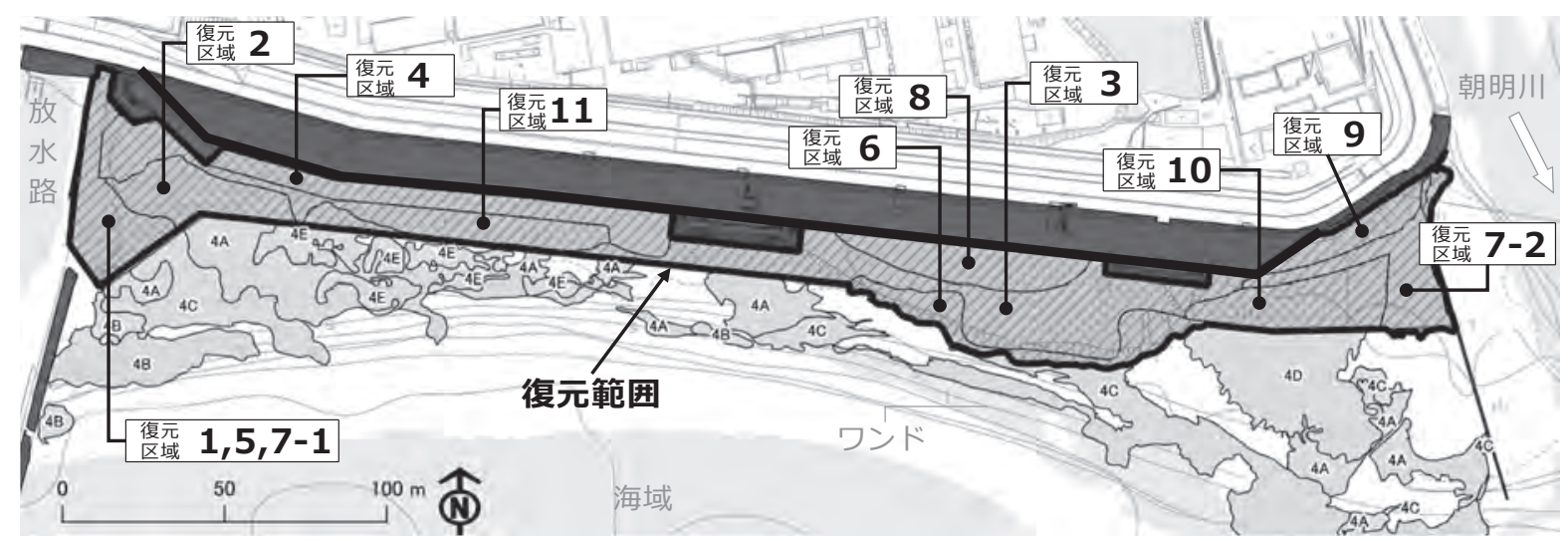

【復元範囲外に残存する海浜植生（2018 年調査時）】

4A: コウボウムギ群落，4B:八マヒルガオ群落，4C:コウボウシバ群落，4D:八マゴウ群落，4E:ケカモノハシ群落

\begin{tabular}{|c|c|c|}
\hline 復元区域 & $\begin{array}{c}\text { 復元目標群落 } \\
\text { 移植植物 }\end{array}$ & 配植根拠 \\
\hline $1,5,7-1, \quad 7-2$ & $\begin{array}{c}\text { (1)コウボウシバ群落 } \\
\text { コウボウシバ }\end{array}$ & $\begin{array}{l}\text { ・河川, 放水路，ワンド側に傾斜する，地盤高のやや } \\
\text { 低い区域 } \\
\text { ・コウボウシバ群落が成立する地盤高 } \\
\text { ・復元範囲外のコウボウシバ群落 (4C) に隣接 }\end{array}$ \\
\hline 2,6 & $\begin{array}{l}\text { (2)コウボウシバ群落 } \\
\text { コウボウシバ } \\
\text { ケカモノハシ }\end{array}$ & $\begin{array}{l}\text { ・放水路, ワンド側にやや傾斜する, 地盤高のやや低 } \\
\text { い区域 } \\
\text { ・コウボウシバ群落, 安定帯のケカモノハシ群落が成 } \\
\text { 立する地盤高 } \\
\text { ・復元範囲外のケカモノハシ群落 }(4 \mathrm{E}) \text {, コウボウシ } \\
\text { バ群落 }(4 \mathrm{C}) \text {, コウボウムギ群落 }(4 \mathrm{~A}) \text { に隣接 }\end{array}$ \\
\hline 3 & $\begin{array}{l}\text { (3)コウボウムギ群落 } \\
\text { コウボウムギ } \\
\text { ハマゴウ } \\
\text { ケカモノハシ }\end{array}$ & $\begin{array}{l}\text { ・陸側の海岸堤防に近い地盤高の高い区域 } \\
\text { ・コウボウムギ群落, 安定带のケカモノハシ群落 }(4 \mathrm{E}) \text {, } \\
\text { ハマゴウ群落 (4D) が成立する地盤高 } \\
\text { ・復元範囲外のコウボウムギ群落 (4A), 範囲内の(4) } \\
\text { ケカモノハシ群落, (5)ハマゴウ群落に隣接 }\end{array}$ \\
\hline 11 & $\begin{array}{l}\text { (4)ケカモノハシ群落 } \\
\text { ケカモノハシ } \\
\text { ユウボウムギ } \\
\text { コウボウシバ }\end{array}$ & $\begin{array}{l}\text { ・陸側の海岸堤防に近い地盤高のやや高い区域と地盤 } \\
\text { 高のやや低い放水路側の区域 } \\
\text { ・コウボウシバ群落, コウボウムギ群落, 安定帯のケ } \\
\text { カモノハシ群落が成立する地盤高 } \\
\text { ・復元範囲外のコウボウムギ群落 (4A) やケカモノハ } \\
\text { シ群落 (4E) に隣接 }\end{array}$ \\
\hline 4,8 & $\begin{array}{l}\text { (5)ハマゴウ群落 } \\
\text { ハマゴウ }\end{array}$ & $\begin{array}{l}\text { ・陸側の海岸堤防に隣接した地盤高の高い区域 } \\
\text { ・ハマゴウ群落が成立する地盤高 }\end{array}$ \\
\hline $9, \quad 10$ & $\begin{array}{l}\text { (6)ハマゴウ群落 } \\
\text { ハマゴウ } \\
\text { コウボウシバ }\end{array}$ & $\begin{array}{l}\text { ・河川側にやや傾斜した，地盤高のやや低い区域 } \\
\text { ・安定帯のハマゴウ群落，コウボウジ群落が成立す } \\
\text { る地盤高 } \\
\text { ・ハマゴウ群落 (4D) に隣接 }\end{array}$ \\
\hline
\end{tabular}

Fig. 6. Arrangement of beach vegetation and its reason. 海浜植生の配植とその設定理由. 


\section{移植方法の決定}

海浜植生の復元は, 当初種子移植による実施を検討し ていた。 2014 年に試験的に実施した種子移植（冷湿処 理のみ，薬品などによる処理は行っていない) では, 八 マゴウ (播種量 $769 \mathrm{~g}$ ), ケカモノハシ (同 $523 \mathrm{~g}$ ), コ ウボウムギ (同 $1,143 \mathrm{~g}$ )，コウボウシバ (同 $621 \mathrm{~g}$ ) の うち, 発芽個体を確認できたのはコウボウムギとコウボ ウシバの 2 種のみであった (2016 年調查時)。いずれも 数個体の確認にとどまったため, 海浜植生の復元手法と して採用することは難しいと判断した。 そこで, 2015 年にハマゴウ (匍匐荎), ケカモノハシ (株), コウボウ ムギとコウボウシバ（いずれも地下茎つき苗条）の植物 体を用いた試験移植（以下，植物体移植という）を行い, 移植方法を再検討した。 モニタリングの結果，移植した 4 種の植物体は全て活着していた（2017 年調査時）。こ のため, 植物体移植は移植による海浜植生の復元効果が 高いと判断し, 本方法を海浜性植物の移植方法として決 定した。

\section{復元工事}

\section{技術的助言}

整備撤去範囲を対象にした海浜植生の復元工事は,
「臨港道路霞 4 号幹線事業実施に伴う懇談会」の助言を 得ながら，2016 年の概略検討，2017 年の詳細検討の各 段階を経て，2018 年 8 月の整備撤去範囲の整地から開 始した。 その後， 9 月から 10 月には八リエンジュやセ ンダンなどの低木林の伐採・除根とその跡地の整地が行 われ，移植工事は 10 月 24 日から 2019 年 1 月 29 日の約 3 ヶ月間にわたり実施した。この復元工事の期間中, 施 工業者は突発的な様々な事象に対する対応が求められる。 このため, 次項で示す作業手引書に基づいた事前教育に 加え, 復元工事の各施工段階において, 施工業者に対す る技術的助言を実施している。復元工事期間中に実施し た助言指導の回数は計 9 回に及んだ。現地での助言指導 の内容は，作業手引書には記載のない，主に海浜性植物 の調達時と植え戻し作業に関する事項が多い。例えば, 復元植物の確認方法 (外来植物や内陸性植物との違いを 実物で示す), 調達範囲で移植苗の想定数量を確保でき ない場合の対応，地下茎や匍匐茎の伸長方向を踏まえた 植え戻し方法 (伸長阻害を避けるため), 移植苗の植え 戻し状況（土極めの状態）の確認方法などがある.

\section{作業手引書による指導}

海浜植生の復元工事を行う施工業者には, 高松海岸の

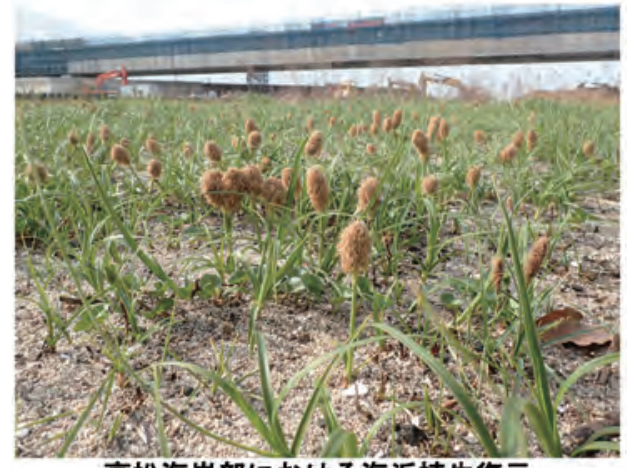

高松海岸部における海浜植生復元

『作業手引書』

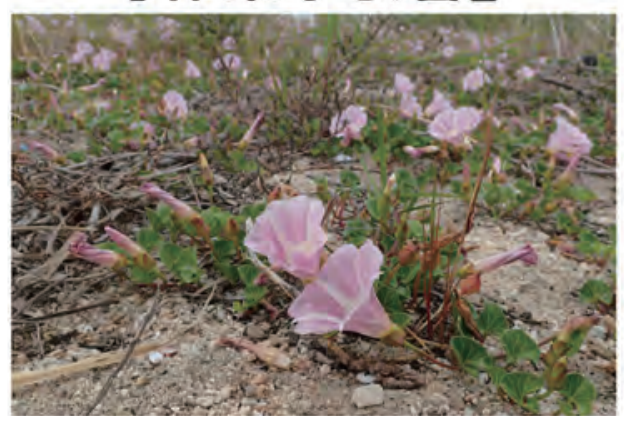

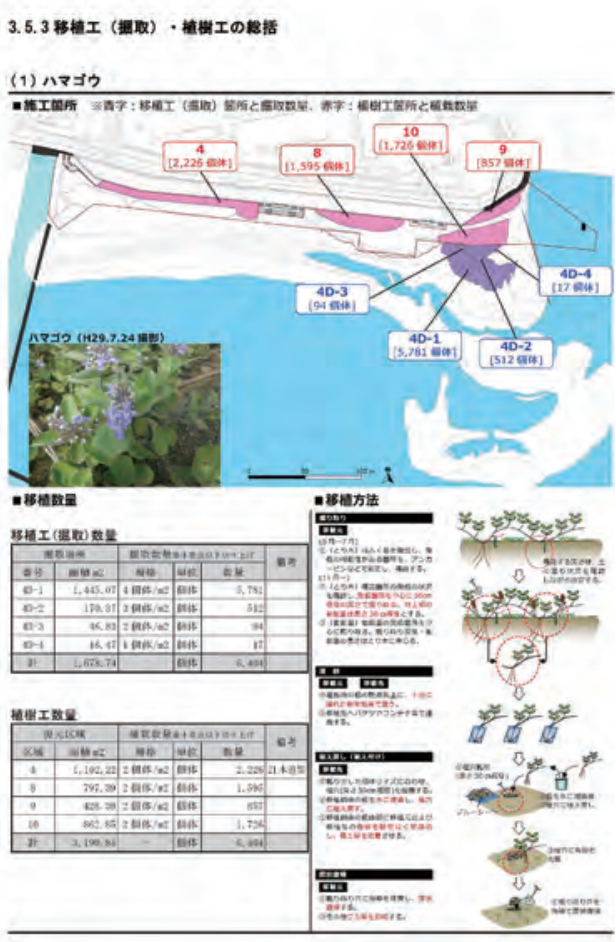

Fig. 7. Work guide for beach vegetation restoration. 海浜植生復元のための作業手引書. 
環境についての理解を深め, 環境保全に対する意識の向 上を図ることが重要である。このような点を踏まえて作 成したのが「高松海岸部に扔ける海浜植生復元 作業手 引書」である（Fig. 7)，復元工事の手順を整理するだけ でなく, 高松海岸の環境について理解した上での作業が 可能となるように整理したもので，事前に復元工事の施 工業者に配布し, 環境配慮の必要性の理解を作業員に周 知徹底を図った。

\section{配植図を用いた移植指導}

作業手引書には移植密度の記載はあるものの, 個々の 植物の移植位置の詳細については記載されていない。 そ こで，効率的に移植作業を進めるため，植生分布との連 続性を踏まえた，整備撤去範囲内の「配植図」を検討し， 施工業者に提示した，ただし，他の生物の利用可能な環 境（裸地など）の創出のため, 配植図の変更を柔軟に行 うように指導した。

\section{現地で 18,440 株の海浜性植物を調達}

海浜植生の復元のために使用する海浜性植物は, 高松 海岸内で調達するため, 調達可能な数量は限られている. この限りある資源を復元材料として確実に使用するため, 掘り取り作業前に海浜植生への影響が少ないと判断され る場所を調達（採取）場所として選定し，マーキングし た (Fig. 8の (1)).

調達（採取）場所での掘り取り作業は, 一日に移植で きる数量のみを掘り取ることとし，取り置きすることは しなかった。これは，取り置きに伴う移植苗の衰弱を避 けるためである。また，掘り取りの際には，例えば匍匐 茎を復元の材料とするハマゴウの場合，匍甸茎にある不 定根と翌春に出芽する新芽の欠損に，またコウボウムギ やコウボウシバの場合は地中を横走する新芽の欠損に十 分な注意を払い，移植苗が可能な限り健全な状態で植え 㞍しできるよう配慮した（Fig.8の(2)）。このほか，海 浜植生復元の対象とはしなかったハマヒルガオ（群落） は，他の海浜性植物と混生していることが多い。このた め, 他の海浜性植物と一緒に掘り取った場合は, そのま ま使用した。 また, 掘り取り時の移植苗の状態を確認し, 外来植物や内陸性植物が混生していた場合は, その場で それらを取り除き，外来植物などの復元範囲への持ち込 みを回避した。しかし, 事前に海浜性植物と外来植物な どの違いは周知していたものの，施工業者だけでは，掘 り取り作業中にこれらの植物を見分けることが困難にな る場合がある。このため, 新たな海浜性植物の掘り取り 作業開始日には，海浜性植物と外来植物などの違い，掘 り取り個体に混入している外来植物などの有無について
再度指導することで, 施工業者の理解が深まるよう配慮 した。

掘り取り場所から一時仮置き場あるいは移植先（植え 戻し場所）へは，移植苗を‘み’などに積載し，人力で 運搬した（Fig.8の (3)）。これは，一輪車などを使用し た運搬が及ぼす整備撤去範囲外の海浜植生への損傷を最 小限に抑えるための配慮として実施したものである。ま た, この運搬ルートも現地で確認し, 設定した.

\section{植え戻し作業}

植え戻し作業では，限られた資源を確実に，かつ有効 に使用するため，掘り取った全ての移植苗を当日に植え 戻した。 また，水の吸い上げが悪いハマゴウのような海 浜性植物の場合, 移植苗は掘り取り後に急速に衰弱する. このため, 移植苗は水を張ったプラ船に十分に浸漬した 後，植え戻しをするよう配慮した（Fig.9の１）.

また，植え戻す際には，いくつかの配慮が必要となる． 第一に植穴掘削時の配慮である。海岸の地表面は乾燥し ているため, 移植苗の植え戻しには不適なためである. しかし, $10 \mathrm{~cm}$ より深く位置まで掘り下げることで, 湿 り気を带びた層が出現する。この点に注意し, 移植苗の 根がこの湿り気を带びた層に確実に埋設できるよう, 植 穴を掘削することが重要である（Fig.9 の(2)）。第二に， 現地調達した移植苗の大きさは, 購入苗とは異なり, 一 定ではない．先述した新芽や根を損傷させてないために も，一つ一つの移植苗の大きさに合わせた植穴を掘削し なければならない、第三に, 移植苗を植穴に配置し, そ の隙間を海砂で充填する際には, 移植苗の根と海砂が密 着するよう，指や棒を使って十分に土極めをする必要が ある（Fig. 9 の (3) (4)）。移植後の活着率に大きく影響す るため, これらの配慮事項を踏まえた植え戻し作業を丁 寧に行うことは極めて重要な工程である。

\section{集中灌水の実施}

植え戻し完了後, 植え戻し箇所に灌水作業を行った。 一般的に行われる灌水作業は, 植物を移植した範囲全体 に水を撒く、いわゆる「散水」を行うことが多い. しか し, 今回, 植え戻し作業を行った海岸は, 透水性の高い 砂浜という特殊な環境下にあるため, 散水後の砂中の水 分は短時間で排水されてしまう。このため, 移植苗の根 に十分な水分を供給することができない.コウボウムギ やハマゴウなどのように, 新芽が出芽あるいは伸長して いる植物にとって，このような時期の水分の枯渴は，植 物体の衰弱あるいは枯死に直結する。このことから，今 回は，対象範囲全体に水を撒く，一般的な「散水」を行 うのではなく, 植え戻し場所 1 箇所ごとに, 地表面に水 
(1)マーキング ※事前に残存する海浜植生への影響の少ない個体を選択

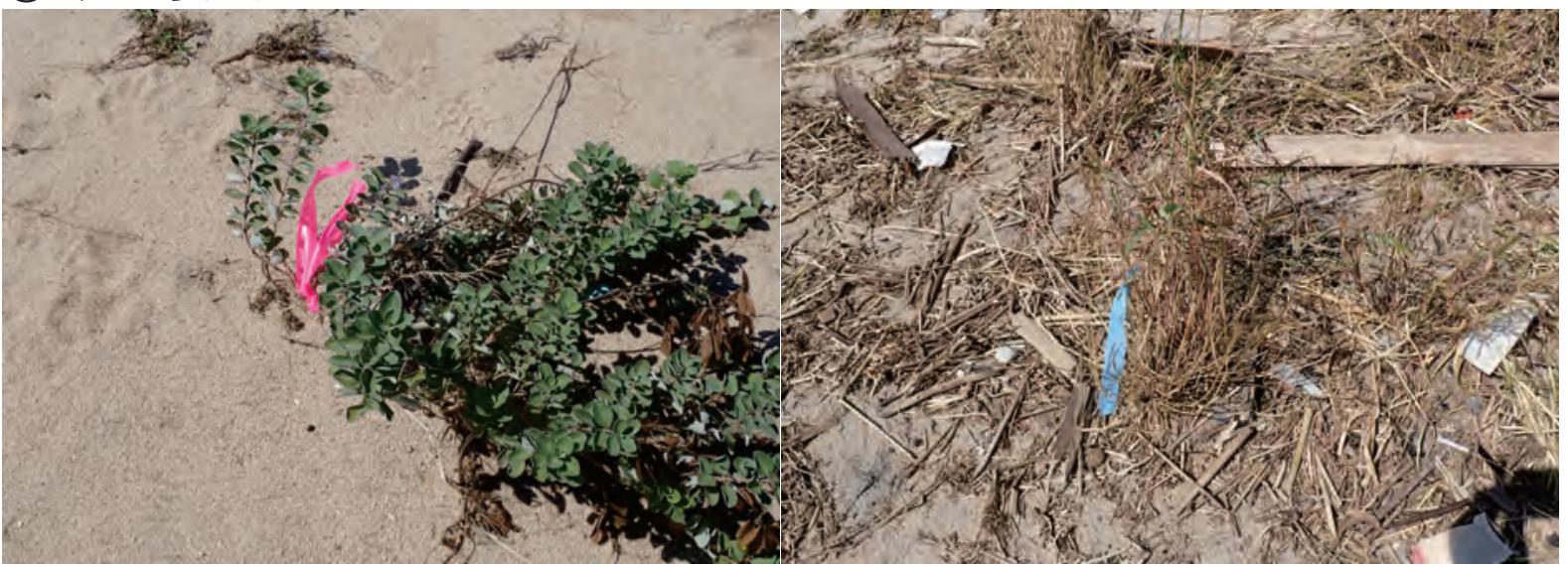

八マゴウ(2018.9.19 撮影)

ケカモノ八シ(2018.10.9 撮影)

(2)丁盡な掘り取り ※苗条や新芽の出芽状況，根の状態の確認

※外来植物や内陸性植物を選別・除去し，復元範囲への持ち込みを防止 ※海浜性植物が混生する場合は，まとめて掘り取り

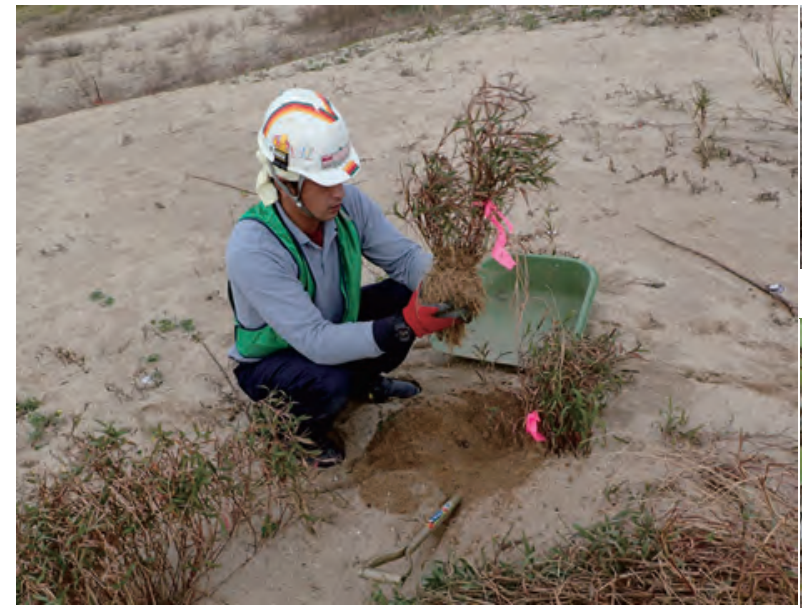

ケカモノハシ(2018.11.5 撮影)

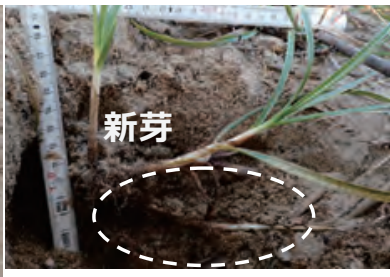

コウボウムギ(2018.9.28 撮影)

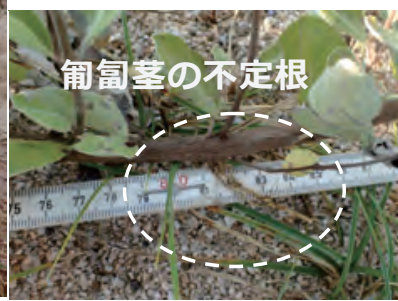

ハマゴウ(2018.9.28 撮影)

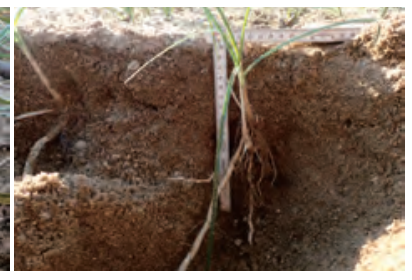

コウボウシバ(2018.9.28 撮影)

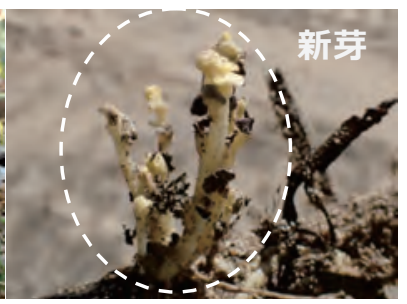

八マゴウ新芽(2018.9.28 撮影)

(3)人力で運搬 ※運搬時の海浜植生への損傷を回避

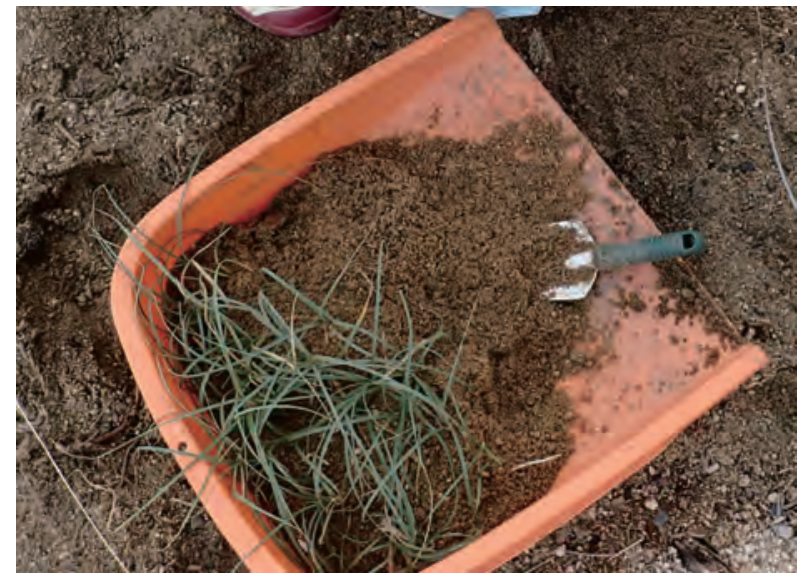

コウボウシバ(2018.10.24 撮影)

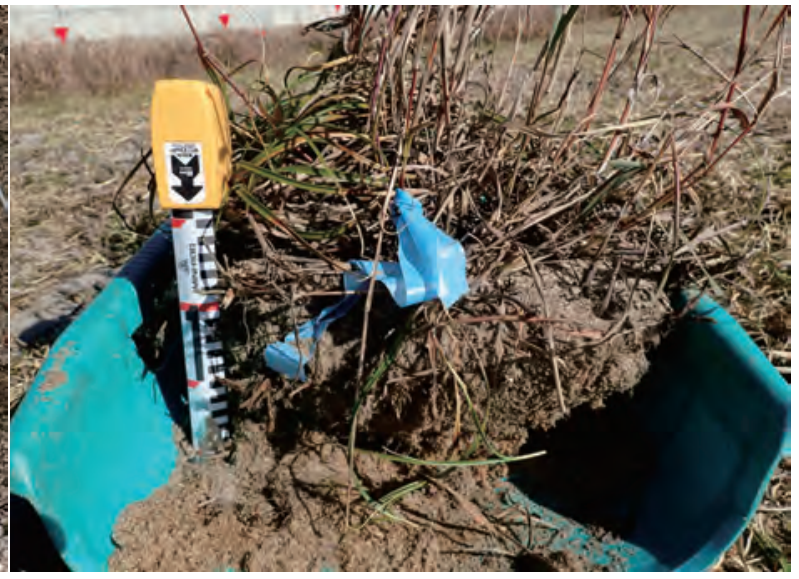

ケカモノハシ(2018.11.21 撮影)

Fig. 8. Collecting beach plants. Repeat steps (1) to (3). 海浜性植物の調達. (1)(2)(3)手順を繰り返す. 
(1) 準備 ※移植苗を植え戻し前に十分に浸漬

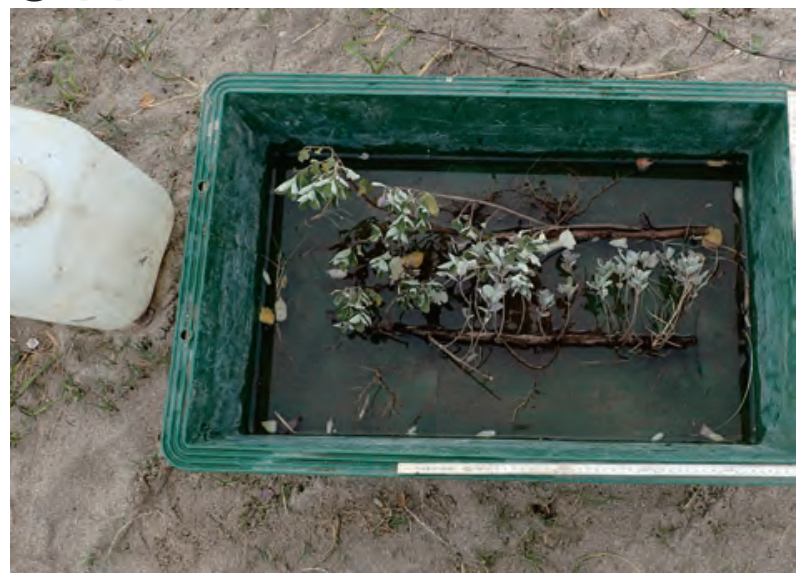

ハマゴウ(2018.11.5 撮影)

\section{(2)植穴の掘削 ※湿り気を帯びた層（地表面から $10 \mathrm{~cm}$ 以深）まで掘削}
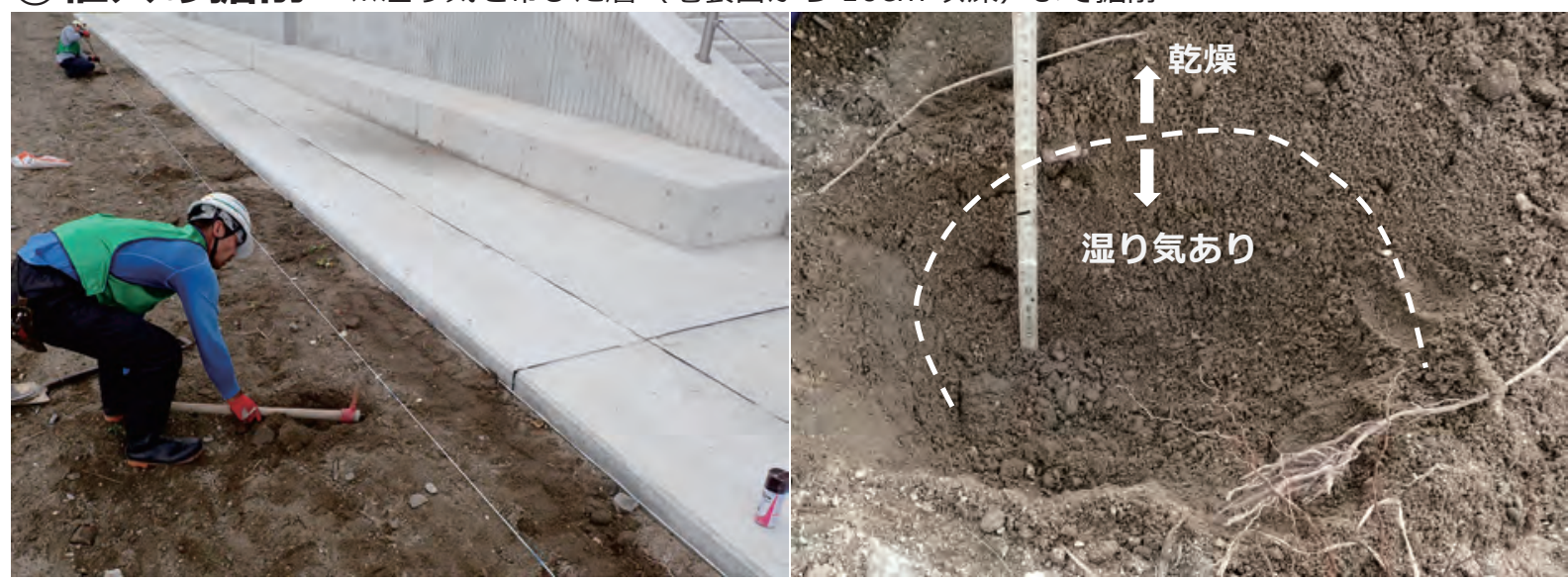

(2018.11.5 撮影)

(2018.11.5 撮影)

(3)植え戻し ※新芽の損傷に注意しながら，植穴に根や匍匐茎を配置し，海砂で埋設

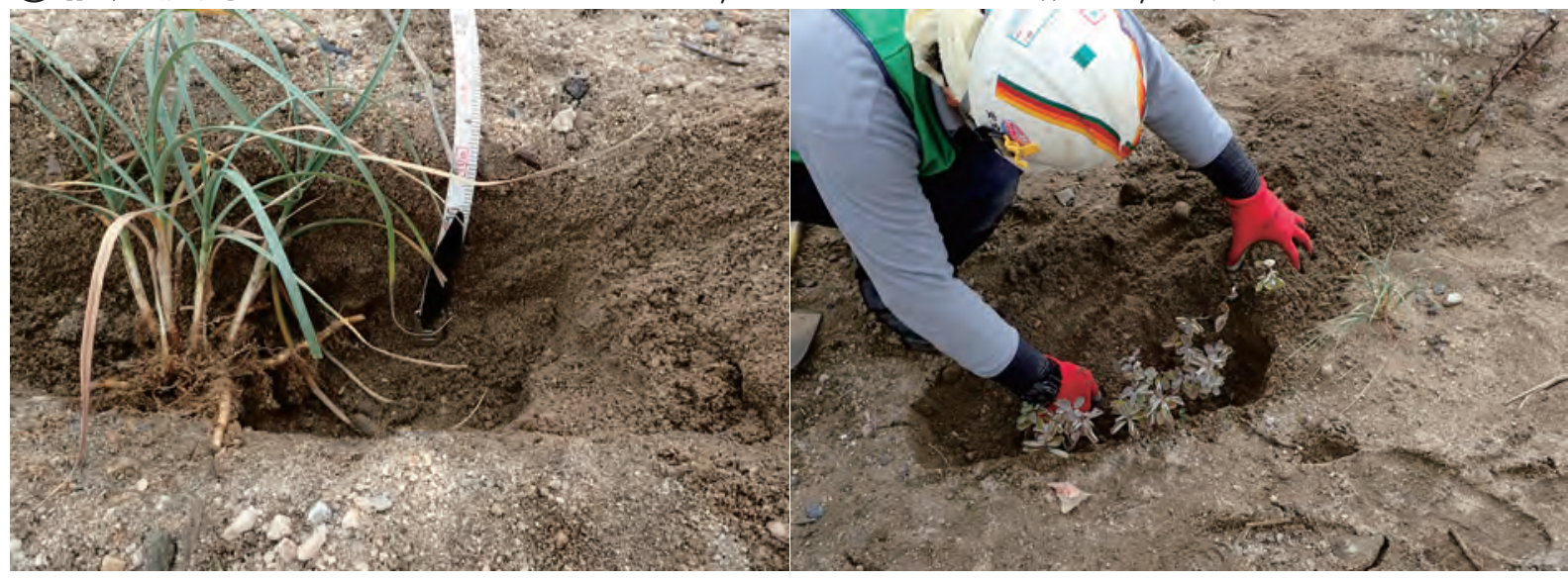

コウボウシバ(2018.11.5 撮影)

ハマゴウ(2018.11.5 撮影)

Fig. 9. Replanting work of beach plants. Repeat steps (1) to (4). 海浜性植物の植え戻し作業. (1)(2)(3)の手順を繰り返す. 
(4)土極め ※指や棒で突いて，根 ・匍甸茎の隙間に海砂を充填

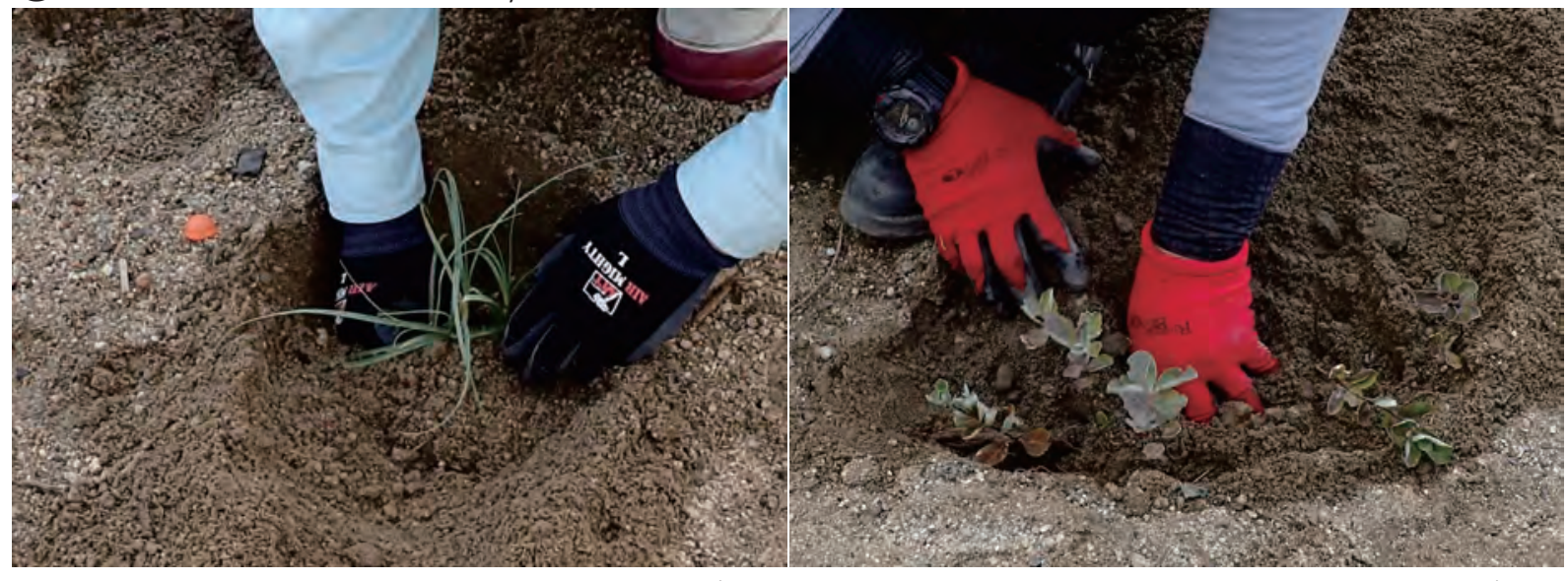

(2018.10.24 撮影)

(2018.11.5 撮影)

Fig. 9. Replanting work of beach plants. (Continued) 海浜性植物の植え戻し作業. (続き)

集中灌水 ※植栽した全ての箇所を対象に，集中灌水を実施

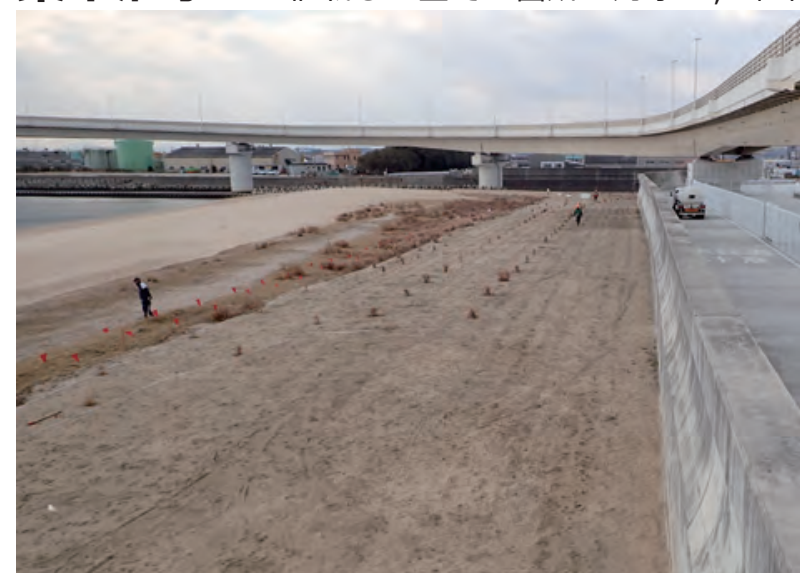

灌水作業(2019.1.29 撮影)



コウボウシバ(2018.10.24 撮影)

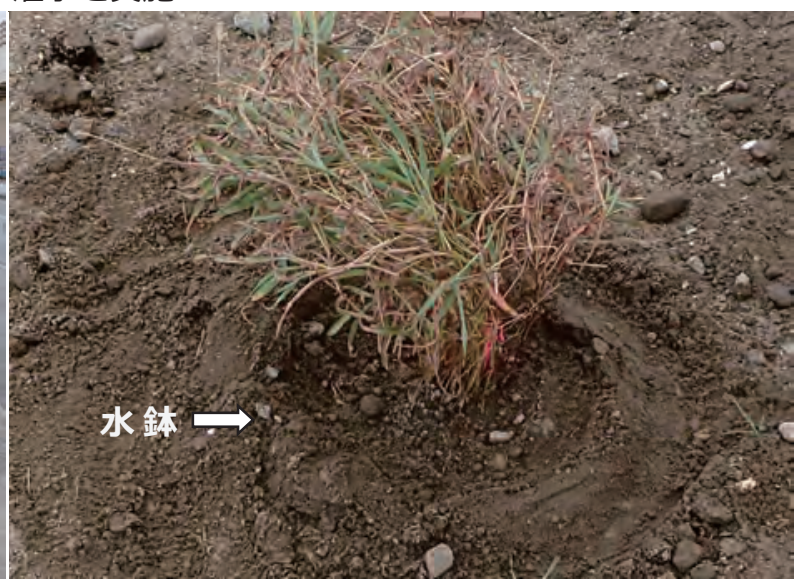

ケカモノハシ(2018.10.24 撮影)

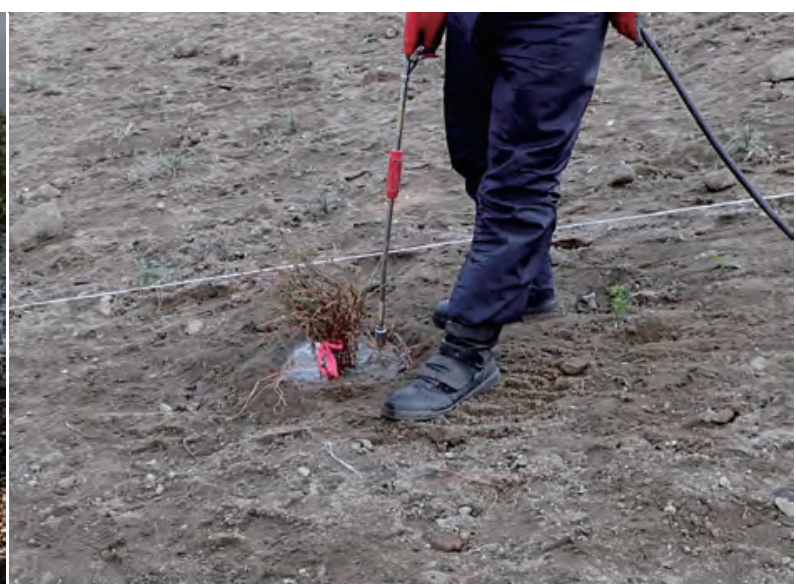

ケカモノ八シ(2018.11.5 撮影)

Fig. 10. Work status of intensive watering. 集中灌水の作業. 
が浮き出るまで水鉢に灌水する「集中灌水」を実施した (Fig. 10)。この作業は, 休工日や雨天を除き, 復元工事 期間中毎日実施することを原則とした。丁寧な植え戻し 作業に加え，移植苗に対して，十分な水分を長期にわた って定期的に供給するという維持管理を行うことで，植 え戻し後の移植苗の衰弱を抑え, 活着率の向上を図った。

\section{考 察}

\section{技術的成果}

整備撤去範囲を対象にした海浜植生の復元工事は高松 海岸の植生分布は概ね概略・詳細検討で想定したものに 近い状態で完了した（Fig. 11）。今回のような海浜植生 の復元を確実に行うためには,

(1)海岸の地盤高と海浜性植物（群落）との関倸を把握し,

目標とする植生や配植を決定する

(2)海岸の地域固有性を考慮し，復元工事に使用する海浜 性植物は工事範囲外の海浜植生から現地調達する

(3)移植後には十分な管理（集中灌水）を一定期間行う という一連の工程を適切に実行していくことが重要であ る.

海浜部は保水力の劣る砂土で形成されているため, 植 物が有効に利用できる水分を十分に保持することが難し い. 特に, 少雨となる晚秋から冬季にかけては, 植物に とって水ストレスの影響をより強く受ける季節である. 10 月下旬から開始した移植工事の課題の一つは, この ような悪条件下で移植した海浜性植物の多くが，移植直 後に水ストレスによって枯死に至る可能性があることで あった，今回，復元工事完了時点に扔いて，移植した 4 種の海浜性植物の 9 割程度は新芽の出芽を確認すること ができた。このことは，長期間にわたって実施した集中 灌水が, 初期活着の確度を上げるうえで特に重要な工程
であり，また海浜植生を保全する際の一つの手法として 参考になれば幸いである。

\section{課題}

集中灌水は海浜性植物の初期活着に一定の効果があっ たと考えられる。しかし，その後の海浜性植物の生残あ るいは成長，それに伴う海浜植生の復元の程度には不確 実性を伴う。海浜植生の復元効果や外来植物などに対す る適切な維持管理の必要性を判断するためには, 復元し た海浜植生の状況を定期的に確認していかなければなら ない.

一方, 今回の海浜植生の復元は, 移植密度を最小数量 に抑えて移植しているため, 復元工事完了後の復元範囲 には裸地部が広く存在する。このような裸地部の存在は, 外来植物や内陸性植物の侵入 ·定着の機会を与えること になるため, これらの植物の動向にも注意が必要である.

\section{今後の展望}

\section{高松海岸の環境保全}

高松海岸では, 復元工事完了後の高松海岸が地域住民 や海岸利用者にとってより親しみやすい場所になるよう， 「利用」と「保全」の両面から今後の取り組みのあり方 について意見交換した「高松海岸の利用と保全に関する ワークショップ」(2015 年度〜2016 年度, 計 6 回開催) を開催している。このワークショップの成果をとりまと めた『高松海岸の利用と保全に関する取り組み事例（概 要版)』(高松海岸の利用と保全に関するワークショップ

(編) http://www.yokkaichi.pa.cbr.mlit.go.jp/file/content/ file/jigyo/takamatu-torikumi/torikumijirei-gaiyou.pdf, 2021 年 2 月 23 日確認）には，復元した海浜植生を維持する ための具体的な取り組み例（外来植物や内陸性植物の除 草, 海浜性植物の夕ネまき, 清掃活動団体との連携な

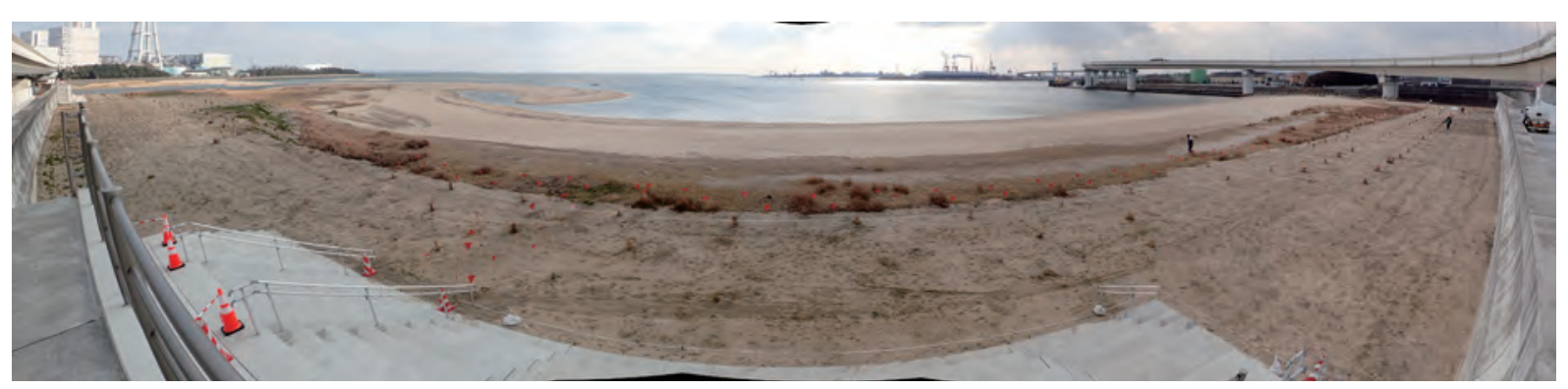

(2019.1.29 撮影)

Fig. 11. Completion of restoration construction of beach vegetation on Takamatsu coast. 高松海岸における海浜植生の復元工事の完了. 
ど）が記載されている。取り組み内容には専門的な知識 を有する内容も含まれているため, 必要に応じて, 専門 家の参画も検討しなければならない.しかし，このよう な事例集を参考に, 地域住民, NPO, 行政機関などが連 携・協力しながら, 復元した海浜植生を含めた高松海岸 の環境保全が進むことに期待したい.

\section{外来植物などへの対応}

海浜植生への影響を最小限に, 外来植物や内陸性植物 を防除（駆除）するためには，(1)人力による「抜き取 り」と「刈り取り」の実施，(2)対象となる外来植物など の特性に合わせた実施（例えば, 多年生植物の場合, 地 下茎からの新たな苗条の再生を防止するため, 地下茎か らの「抜き取り」もしくは生長期間中に「刈り取り」を 繰り返す), (3)「抜き取り」「刚り取り」後の再定着や種 子落下を防ぐため, 刈り草は海岸から搬出し, 焼却など の処分をする，といった注意点がある。このような注意 点は, 「高松海岸に抢ける海浜植生復元 維持管理の手 引き-除草についてー」(以下, 管理の手引き) として まとめている (非公表)。海浜植生復元後の維持管理の 理解を深め, かつ実働可能な取り組みとして継続してい くためには，このような情報を広く一般に提供すること が大切であり, 今後の活用に期待したい.

一方, 復元工事後の海浜植生が安定した群落を形成す るまで, 外来植物などの侵入を抑えるためには，定期的 な維持管理の実施が望まれる。高松海岸では, 定期的に 「伊勢湾 森・川・海のクリーンアップ大作戦」あるいは 「海岸清掃（川と海のクリーン大作戦）」といった海岸清 掃が行われている。このような地域活動の一つとして, 上述した「管理の手引き」や必要に応じて専門家の助言 を得ながら，防除活動を進めていくことができれば，継 続的な取り組みになるものと期待される.

\section{謝 辞}

国土交通省中部地方整備局四日市港湾事務所には，本 事例に関する資料やデー夕の公表に際して，ご理解と多 大なるご協力をいただいた。ここに記して厚く御礼申し 上げる。

\section{摘 要}

臨港道路「霞 4 号幹線」の整備では, 高松海岸や干潟 の多様な機能の保全を目指し, 各種の環境保全対策を実 施した。これらのうち, 整備に伴い撤去した範囲の海浜
植生を復元する，全国的にも少ない技術事例を報告する， 復元する植生の配置は, 整備撤去範囲外に残る海浜植生 との連続性や地形条件を考慮して決定した。また，復元 に使用する海浜植物は, 復元群落の面積と植栽密度から 必要数量を算出し, 整備撤去範囲外の海浜植生から調達 した。 また, 復元工事の施工時には, 施工業者に対し, 復元作業手引書に基づいた現地指導を行った.

\section{引用文献}

独立行政法人 森林総合研究所 東北支所（2015）津波被害軽 減機能を考慮した海岸林造成の手引き一海岸林を造成・管 理する実務者のために一，東北支所，岩手．

早坂大亮・藤原一繪（2006）神奈川県湘南海岸に現存する海 浜植物群落の成立要因. 日本緑化工学会誌 32: 346-354.

林良嗣・莱原淳 (2017) 道路建設とステークホルダー 合意 形成の記録一四日市港臨港道路霞 4 号幹線の事例より。明 石書店, 東京.

楠瀬雄三・石川攧吾 (2014) 米子市弓ヶ浜の離岸堤によって 再生した海浜に抢ける海浜植物の分布特性. 植生学会誌 31: 1-17.

三重県農林水産部みどり共生推進課（2008）三重県レッドデ ータブック 2015 三重県の絶滅のおそれのある野生生物 〜. 三重県農林水産部みどり共生推進課, 三重.

宮本雅美・西川洋子（1999）石狩海岸における海浜植生の復 元試験. 北海道環境科学研究センター所報 26: 78-81.

宮脇昭 - 奥田重俊編（1990）日本植物群落図説. 至文堂, 東 京.

野口英昭（2009）遠州灘海岸における防潮堤の緑化実験。日 本緑化工学会誌 35(4), 508-512.

岡浩平（2009）海岸環境と生物多様性一海浜植生の保全・復 元を事例に一. 日本緑化工学会誌 35(4), 503-507.

岡浩平 ·吉崎真司 - 小堀洋美 (2007) 神奈川県大磯町の湘南 海岸における地形変化に伴う海浜植生の定着過程について。 日本緑化工学会誌 33: 27-32.

臨港道路霞 4 号幹線調查検討委員会 (2003a) 臨港道路霞 4 号 幹線調查検討作業報告書（http://www.yokkaichi-port.or.jp/ kasumi_r4/pdf/houkokusho_gaiyou.pdf, 2021 年 2 月 23 日確 認).

臨港道路霞 4 号幹線調查検討委員会（2003b）提言と付带意 見及び道路ガイドプラン (http://www.yokkaichi-port.or.jp/ kasumi_r4/index.html, 2021 年 2 月 23 日確認).

清水一 (2016) 北海道に打ける海浜植物の増殖と導入の事例. 20 (2): 83-100.

鈴木清 (1974) 海岸砂地固定植物としてのコウボウムギ (Carex kobomugi Ohwi）の利用関する研究. 神奈川県林業試験 場研究報告 2: 1-28.

高松海岸の利用と保全に関するワークショップ（編）（2018） 高松海岸の利用と保全に関する取り組み事例（概要版） (http://www.yokkaichi.pa.cbr.mlit.go.jp/file/content/file/jigyo/ takamatu-torikumi/torikumijirei-gaiyou.pdf, 2021 年 2 月 23 日確認).

田中規夫 · 渡辺肇 - 谷本勝利 - 小松原肇（2002）海浜植生コ ウボウムギの生長捛よび平面拡大解析. 海岸工学論文集 49: 506-510. 